鼻副鼻腔悪性リンパ腫の診断と治 療一司会の言葉

千葉大学 大学院医学研究院 耳鼻咽喉科 頭頸部腫瘍学

○岡本 美孝

1994 年のリンパ腫に関する REAL分類に続いて 2001 年に WHO の新分類が発表された。従来の 病理組織学的所見に加えて免疫学的解析、遺 伝子解析などの新しい検查法がこれらの分類 には取り入れられている。この中の節外性鼻 性 NK／T 細胞リンパ腫は、頻度は決して高く はないが中高年に好発し、鼻を中心に上気道 に壊死性、肉芽腫病変を形成する非常に予後 が不良な疾患であることはよく知られてい る。ただ、実際の治療は血液内科、放射線科 にまかされていることが多く、精通している 耳鼻科医は必ずしも多くはない。また、現在 では病態研究, 各種臨床試験の進展から予後 の改善が大きく期待されている疾患である。 しかし、そのためには早期の的確な診断が重 要であり、さらに局所清浄、治療後の経過観 察も含めて本疾患への我々耳鼻科医の積極的 な参加が望まれる。一方、本疾患は Epstein-Barr（EB） ウイルスが高率に検出さ れ、EB ウイルス関連疾患であることが明らか となっており、その DNA 定量は診断, 予後判 定，さらには治療法にも利用されている。し かしながら、同じ EB ウイルス関連腫瘍疾患と してよく知られている上咽頭癌とは近接した 臓器に発生しながらその病像は大きく異なっ ており、その解明は興味深い。このような 点を踏まえ今回の本教育パネルでは、参加者 が鼻性 $\mathrm{NK} / \mathrm{T}$ 細胞リンパ腫の特徵的な病態、 臨床像を把握し、本疾患の治療に積極的に参 画出来ることを目的とした企画を進めたい。
鼻性 NK/T 細胞リンパ腫の疫学と診 断

旭川医科大学 医学部 耳鼻咽喉科・頭頸部 外科

○荻野 武、原㴊 保明

我々の悪性リンパ腫に対する検討では、頭 頸部原発悪性リンパ腫の約 $20 \%$ は鼻腔原発で あり、その約 $80 \%$ は鼻性 $\mathrm{NK} / \mathrm{T}$ 細胞リンパ腫で あった。したがって、耳鼻咽喉科医が扱う悪 性リンパ腫の約 16\%は鼻性 NK/T 細胞リンパ腫 であり、我々耳鼻咽喉科医は本疾患について 熟知する必要があると言える。本疾患は若年 から中年齢層（40 歳代にピーク）に多くみら れ、特に性差はない。また地域特異性があり、 極東アジア（中国、台湾、韓国、日本）の他、 ペルーに多くみられる。本疾患の診断は迅 速にすることが重要である。鼻内および口腔 内病変の広がりを診察、画像にて評価する。 破壊性病変の大きい症例は予後が不良であ る。生検材料を得る際には、壊死や潰瘍病変 だけを採取するのではなく、その周囲の一見 正常と見える部位も含めて、できる限り大き く採取した方が確定診断に至りやすい。生検 材料は一般的な悪性リンパ腫の検査と同様に ホルマリン固定だけでなく、遺伝子再構成検 査用、フローサイトメトリー用も用意する。 上部、下部消化管、胸腹部 CT、マルク等全身 検索を行い、病期を決定する。本疾患の特徵 である EB ウイルスの関与の観点から、生検材 料の EBER ISH や血清 EB ウイルス抗体価、血 清 EB ウイルス DNA 量の測定は有用な情報とな る。特に EBER ISH は診断の決め手になる場合 があり、EB ウイルス DNA 量は本疾患の病勢と 相関し、EB ウイルス関連腫瘍のマーカーとし て最近注目されている。本パネルでは当科 における統計や診断法を提示しつつ、鼻性 $\mathrm{NK} / \mathrm{T}$ 細胞リンパ腫の疫学と診断について概説 する。 
鼻性 NK/T リンパ腫の病態

金沢大学 大学院 医学系研究科

○吉崎 智一

鼻性 NK/T リンパ腫は Epstein-Barr ウイルス （EBV）関連腫瘍である。臨床的に EBV との関 連性を示唆する所見としては 1 ) 生検組織に おいて EBERs といわれる EBV 転写産物が腫陽 細胞の核内に検出される。その確率はほぼ $100 \%$ に近い。2）しばしば EBV 膜蛋白 LMP-1 が検出される。3）鼻性 NK/T リンパ腫患者に おいては Realtime Quantative-PCR 法で血中 EBV-DNA が検出される。などがあげられる。 EBV 関連腫揚は腫場化した組織によりそれぞ れ特徵的な臨床像・病理像 - ウイルス遺伝子 発現パターンを示す。たとえば同じ耳鼻咽喉 科領域の EBV 関連腫瘍である上咽頭がんは、 腫瘍細胞中の $\mathrm{EBV}$ 遺伝子発現パターンは潜伏 感染様式 II 型という共通パターンであるが、 鼻性 NK/T リンパ腫に特徴的な著しい局所壊死 像を呈することはない。また、病理学的にも 壊死に加え angiocentric と表現されるような 微小血管の破壊像を呈することもない。さら には、治療の上で大きな問題となるのである が、上咽頭がんは化学療法および放射線療法 いずれにも高感受性であるのに対して鼻性 NK/T リンパ腫は治療抵抗性である。本学会 教育パネルにおいては、他の EBV 関連腫瘍の 病態と対比させながら、上記のような鼻性 $\mathrm{NK} / \mathrm{T}$ リンパ腫の特徴的な病態について述べ る。さらには、難治であるこの疾患に対する 新たな治療法の糸口を $\mathrm{EBV}$ 関連腫瘍の視点か ら考察する。
NK/T リンパ腫の治療と今後の展望

三重大学大学院医学系研究科 造血病態内科 学

\section{○山口 素子}

NK/T リンパ腫は近年まできわめて難治なリ ンパ腫と認識されていた。しかし 2000 年頃よ り予後改善の手がかりとなる知見が急速に集 積され、あらたな展開をみせている。今回は 鼻 NK/T リンパ腫を中心に、自験成績と文献レ ビューから現在の推奨治療を明らかにすると ともに、予後改善への取り組みを紹介する。

通常の限局期 aggressive リンパ腫では、 CHOP 療法 3 コース後に病変部放射線照射を行 うのが標淮治療とみなされている。しかし、 鼻 NK/T リンパ腫におけるこのような治療法で の 5 年生存率は $50 \%$ に満たず、限局期リンパ腫 の治療成績としては著しく不良であること が、2001 年以来、国内外の研究者から続々之 報じられた。その後、良好な局所制御を得る ためには 45-50 Gy の照射が必要であること、 CT を用いた放射線治療計画が望ましいことが 複数の研究グループにより明らかにされた。 しかし本疾患ではこのように通常のリンパ腫 より高線量の照射を行っても照射野外への再 発が観察されることから、45-50 Gy の照射後 に何らかの化学療法を行うことが現時点での 推奨治療と考えられている。

NK/T リンパ腫に有効な化学療法のレジメン は明らかでない。NK/T リンパ腫は腫瘍細胞に おいて高率に Epstein-Barr virus（EBV）が検 出され、EBV 関連疾患の一つとみなされてお り、近年、EBV 関連疾患における etoposide と L-asparaginase の有効性が報告されている。 JCOG リンパ腫グループでは etoposide を含む 化学療法である DeVIC 療法と照射 50 Gy を同 時開始する治療法 (RT-DeVIC) の第 I/II 相試 験が進行中である。また、NK 腫瘍研究会 (事 務局：nkshuyou@ctime. co.jp)では進行期、再 発・難治例に対して L-asparaginase および etoposide を含む新規化学療法 (SMILE 療法) の東アジア多国間臨床試験を現在実施中であ る。今後、専門領域、研究グループ、国境を 越えた研究・診療連携のさらなる促進によっ て、本疾患の予後が一層改善されることが望 まれる。 